Available online Ta'limi: Journal of Arabic Education \& Arabic Studies Website: https://journal.stai-nuruliman.ac.id/index.php/tlmi

Ta'limi: Journal of Arabic Education \& Arabic Studies, Vol. 1 No. 1, Januari 2022

Diterima: 14/12/2021; Diperbaiki: 20/12/2021; Disetujui: 05/01/2022

\title{
PENINGKATAN PEMAHAMAN TEKS BAHASA ARAB MELALUI METODE (SQ3R)
}

\author{
Parhan, Muhammad Abdul Jalil, Idrus, Mudiono \\ STAI Nurul Iman Parung Bogor, Indonesia, STAI Nurul Iman Parung Bogor, Indonesia, \\ STAI Nurul Iman Parung Bogor, Indonesia, STAI Nurul Iman Parung Bogor, Indonesia \\ walidbagirı@gmail.com, jalilzamrudı@gmail.com, idrus9g@gmail.com, \\ mudiono89@gmail.com
}

\begin{abstract}
The purpose of this study was to determine how the application of the $\mathrm{SQ}_{3} \mathrm{R}$ method in improving understanding of Arabic texts and to determine the extent to which the understanding of Arabic text was increased through the $\mathrm{SQ}_{3} \mathrm{R}$ method. This study used a qualitative approach with a classroom action research (CAR) strategy. The subjects of this study were students of class VII B MTs Nurul Yaqin Legok Tangerang. Sources of data used: (1) informants, namely Arabic teachers in class VII B MTs Nurul Yaqin who are easy to communicate with (2) data or documents, in the form of reading texts, photos of teaching and learning activities, student test results, transcripts of interviews with students and teacher. The data collection technique used was data triangulation which included: (1) observation / observation, (2) interviews, and (3) documentation (4) written test assessments. The research process was carried out in 2 cycles, each cycle consisting of four stages, namely: (1) planning the action, (2) implementing the action, (3) observing, and (4) analyzing and reflecting. Based on the results of research carried out that the $\mathrm{SQ}_{3} \mathrm{R}$ method was able to improve students' understanding of Arabic text. With an average acquisition of 64 on the pre-test results, then increased in cycle I with an average of 84 , then increased again in cycle II with an average result. Average 95.5. with an average comparison of 20 between the pre-test and post-test cycle I, and the comparison between cycle I and cycle II, namely 11.5 .
\end{abstract}

Keywords : Text comprehension, method, $S_{2} R$ 


\section{PENDAHULUAN}

Bahasa memiliki peranan yang penting dalam perkembangan intelektual, sosial, dan emosional peserta didik. Bahasa juga merupakan salah satu aspek penunjang keberhasilan peserta didik dalam mempelajari semua bidang studi. Melalui pembelajaran bahasa, diharapkan peserta didik dapat mengenal dirinya, budayanya, budaya orang lain, mengemukakan gagasan dan perasaan, berpartisipasi dalam masyarakat yang menggunakan bahasa tersebut, dan menemukan serta menggunakan kemampuan analitis dan imaginatif yang ada dalam dirinya (Ambarwati, t.t.).

Ada empat aspek keterampilan berbahasa yang mencakup pengajaran bahasa yaitu: (1) Keterampilan menyimak, (2) Keterampilan berbicara, (3) Keterampilan membaca dan (4) Keterampilan menulis (Ardila \& Hidayah, 2018). Kemampuan membaca pemahaman merupakan bekal dan kunci keberhasilan siswa dalam menjalani proses pendidikan. Sebagian besar pemerolehan ilmu dila-kukan siswa melalui aktivitas membaca. Ilmu yang diperoleh siswa tidak hanya didapat dari proses belajar mengajar di sekolah, tetapi juga melalui kegiatan membaca dalam kehidupan sehari-hari. Oleh karena itu, kemampuan membaca dan kemampuan memahami bacaan menjadi bagian penting dalam penguasaan dan peningkatan ilmu pengetahuan siswa (Burham, 2017).

Belakangan ini banyak sekali metode-metode pembelajaran bahasa yang dapat meningkatkan pemahaman siswa khususnya dalam pemahaman teks. Walaupun bahasa Arab sudah tidak asing lagi bagi pelajar di Indonesia yang mayoritasnya muslim, namun hal itu bukan menjadi tolak ukur dalam meningkatkan pemahaman teks bahasa Arab karena setiap metode memiliki kelebihan dan kekurangan sehingga bagaimana caranya seorang guru mampu menerapkan metode yang tepat bagi siswanya, seperti halnya yang terjadi di kelas VII B MTs Nurul Yaqin Legok Tangerang, di sekolah ini bahasa Arab menjadi pelajaran wajib. Akan tetapi meskipun mereka sudah menempuh tahap belajar selama satu tahun, bahasa Arab mereka masih belum bisa mencapai target yang sudah ditetapkan baik dalam segi pengucapan, tulisan bahasa Arab yang belum mencapai kriteria sebagai seorang siswa madrasah. Dan yang paling penting ialah ketika mereka diberikan pelajaran bahasa Arab berupa teks, mereka sangat terlihat kesulitan dalam memahami teks tersebut, sehingga pemahaman mereka menjadi kurang baik ketika mereka diberikan pelajaran bahasa Arab berupa teks, mereka sangat terlihat kesulitan dalam memahami teks tersebut, sehingga pemahaman mereka menjadi kurang baik (Ubaidillah, komunikasi pribadi, 15 Februari 2017). 
Oleh sebeb itu peneliti mencoba salah satu metode yang diharapkan mampu meningkatkan pemahaman teks siswa dalam belajar bahasa Arab melalui metode yang dikembangkan oleh seorang pria asal Amerika Serikat bernama Francis P. Robinshon di Universitas Negeri Ohio Amerika Serikat yang disebut dengan metode Survey, Question, Read, Recite, Review atau disingkat menjadi (SQ3 R) (Huda, 2015, hlm. 111).

Metode ini digunakan untuk memudahkan siswa dalam memahami isi yang terkandung dalam sebuah teks ,sehingga pemahaman siswa diharapkan bisa lebih meningkat dan baik, maka guru semakin mudah mencapai tujuan-tujuan lainnya yang sudah ditetapkan dalam pembelajaran bahasa Arab. Semua itu dikarenakan guru bahasa Arab di sekolah tersebut belum menerapkan metode yang khusus untuk mempelajari teks bahasa Arab dan peneliti berharap metode $\mathrm{SQ}_{3} \mathrm{R}$ mampu meningkatkan pemahaman siswa pada sebuah teks bahasa Arab.

Berdasarkan literatur review yang berkaitan dengan tema penelitian ini, penulis menemukan ada beberapa penelitian yang berkaitan dengan metode $\mathrm{SQ}_{3} \mathrm{R}$ dalam meningkatkan pembelajaran bahasa Arab, yaitu:

Pertama, Skripsi yang berjudul Upaya meningkatkan hasil belajar siswa pada pembelajaran bahasa arab materi membaca dengan menggunakan metode $\mathrm{SQ}_{3} \mathrm{R}$ : Penelitian Tindakan Kelas di kelas IV MI Al-Istiqomah Kecamatan Katapang Kabupaten Bandung tahun 2017 (Russamsi, 2017). Skripsi ini secara khusus membahas tentang rendahnya hasil belajar siswa dalam pembelajaran bahasa Arab yang belum mencapai Kriteria Ketuntasan Minimum yaitu 7o. Hal tersebut diidentifikasi dari rendahnya minat belajar, kurangnya partisipasi siswa, siswa tidak semangat belajar, bahkan sama sekali tidak pernah bertanya apabila menemukan kesulitan dalam pembelajaran. Oleh karena itu, untuk meningkatkan hasil belajar siswa dalam materi membaca qira'ah perlu digunakan metode $\mathrm{SQ}_{3} \mathrm{R}$ sehingga kegiatan belajar dan pembelajaran lebih menyenangkan dan memudahkan siswa dalam menerima materi.

Kedua, Skripsi yang berjudul „Pengaruh Metode SQ3 R Pada Maharah Al-Qiraah Siswa Dalam Pembelajaran Bahasa Arab Kelas X-Mia Ma Muhammadiyah 1 Malang” tahun 2020 (Akbar, 2020). Hasil penelitian menunjukkan bahwa pencapaian hasil belajar kelas X-MIA (kelompok eksperimen) dalam maharah al-qiraah lebih tinggi dari pada kelas X- IIS (kelompok kontrol), setelah diterapkan metode $\mathrm{SQ}_{3} \mathrm{R}$ sebesar 85,33. Sedangkan pada kelas X-IIS yang diterapkan metode konvensional (ceramah), rata-rata nilai tes akhirnya sebesar 74,oo. 
Dari hasil literatur review diatas, peneliti sebelumnya hanya membahas peningkatan maharah al-qiraah secara umum sedangkan peneliti akan lebih fokus pada maharah al-qiraah dalam pemahaman teks bacaan secara khusus.

\section{METODOLOGI PENELITIAN}

Penelitian ini bertujuan untuk meningkatkan pemahaman teks bahasa Arab dengan menerapkan metode $\mathrm{SQ}_{3} \mathrm{R}$ untuk mendeskripsikan: (1) penerapan $\mathrm{SQ}_{3} \mathrm{R}$ (Survey, Question, Read, Recite, Review) pada pembelajaran bahasa Arab di kelas VII B MTs Nurul Yaqin Legok Tangerang , (2) hasil kemampuan pemahaman teks bahasa Arab setelah menerapkan metode SQ32 (Survey, Question, Read, Recite, Review) di kelas VII B MTs Nurul Yaqin Legok Tangerang. Subyek dari penelitian adalah siswa kelas VII B MTs Nurul Yaqin Legok Tangerang sebanyak 20 siswa yang terdiri dari 6 siswa laki-laki dan 14 siswa perempuan. Penelitian ini menggunakan rancangan PTK model Kemmis dan Mc. Taggart yang terdiri dari 2 siklus. Instrument yang digunakan adalah tes dan lembar observasi aktivitas siswa. Tehnik analisis yang dipakai rata-rata dan prosentase.

\section{HASIL PENELITIAN DAN PEMBAHASAN}

\section{Metode $\mathrm{SQ}_{3} \mathrm{R}$}

Menurut Syaiful Bahri Djamarah (Bahri, 2008, hlm. 134-135), Metode SQ3R umumnya dipakai dalam membaca teks, tetapi dapat juga digunakan dalam membaca artikel untuk studi. Dalam penggunaan metode ini, yang perama kali dilakukan adalah mengadakan survey, yaitu membaca dengan teknik baca-layap bagan-bagian permulaan buku. Jika berdasrkan survey tersebut diputuskan untuk membaca buku yang bersangkutan, maka langkah berikutnya adalah merumuskan pertanyaan (question), sebagai imformasifokus. Setelah pertanyaan yang merupakan imformasi fokus dirumuskan, barulah batang tubuh buku(bab-bab dan seksi-seksi) mulai dibaca( read). Sewaktu membaca ,pikiran harus dipusatkan untuk mencari jawaban atas pertanyaan. Setelah setiap bab atau seksi selesai dibaca, perlu dilihat kembali pertanyaan fokus yang telah dirumuskan untuk bab atau seksi itu dan dicoba mengatakan jawabannya (recite) dengan kata-kata sendiri. Selanjutnya tuliskanlah pertanyaan dan jawabannya itu dengan lugas 
dalam buku catatan bacaan. Jika pada akhir bab terdapat rangkuman sebaiknya dibaca dulu rangkuman itu sebelum merumuskan jawaban atau pertanyaan dimaksud tadi. Pada setiap akhir bab berikutnya, rumusan isi (jawaban atas pertanyaan fokus) bab sebelumnya perlu diulang (review) dan dihubungkandengan rumusan isi yang baru diselesaikan. Menurut Yunus Abidin Metode SQ3 R (Survey, Question, Read Recite, dan Review) pertama kali diperkenalkan oleh Francis Robinson yang dikutip oleh Yunus Abidin. SQ3 $\mathrm{R}$ adalah metode pembelajaran membaca yang terdiri atas lima langkah yakni Survey, Question, Read, Recite, dan Review yang sangat tepat digunakan sebagai metode membaca bahan bacaan ilmu-ilmu sosial. Metode SQ3R merupakan metode untuk meningkatkan pemahaman dan ingatan jangka panjang. Metode ini sangat baik untuk memberikan dorongan bagi siswa dalam proses belajar (Abidin, 2012, hlm. 108-109). Menurut Miftahul Huda, SQ3R merupakan strategi pemahaman yang membantu siswa berpikir tentang teks yang sedang mereka baca. Sering kali dikatagorikan sebagai strategi belajar, $\mathrm{SQ}_{3} \mathrm{R}$ embantu siswa, mendapatkan sesuatu ketika pertama kali mereka membaca teks. Bagi guru, $\mathrm{SQ}_{3} \mathrm{R}$ membantu mereka dalam membimbing siswa bagaimana membaca dan berpikir layaknya para pembaca efektif (Huda, 2014, hlm. 244). Sedangkan menurut Dalman metode $\mathrm{SQ}_{3} \mathrm{R}$ adalah salah satu metode membaca untuk memahami isi bacaan yang menggunakan langkah-langkah secara sistematis dalam pelaksanaannya. Metode $\mathrm{SQ}_{3} \mathrm{R}$ merupakan suatu kaidah membacayang memerlukan seseorang mempersoalkankesesuian maklumat yang terdapat dalam suatu bahan yang dibaca dengan tugasan yang perlu membaca yang terdiri atas lima langkah, yaitu Survey, Question, Read, Recite, Review (Dalman, 2013, hlm. 189).

Metode $\mathrm{SQ}_{3} \mathrm{R}$ ini memiliki proses yang lebih rinci dan memiliki beberapa tahapan, yaitu: Survey, Question, Read, Recite dan Review ( $\mathrm{SQ}_{3} R$ ). Metode $\mathrm{SQ}_{3} \mathrm{R}$ merupakan suatu metode yang bertujuan untuk membantu pembaca memahami secara utuh dan rinci tentang isi suatu teks. Metode ini merupakan metode pembelajaran membaca yang sangat popular. Kepopulerannya disebabkan oleh kaidah-kaidah yang tampak ilmiah, dan juga namanya yang mudah untuk diingat (Aminah \& Emilda, 2020).

\section{Langkah-Langkah Metode SQ3R}

Adapun Langkah-langkah Metode SQ3R adalah sebagai berikut:(Syah, 2013, hlm. 142-143)

a. Survey, maksudnya memeriksa atau meneliti atau mengidentifikasikan seluruh teks. 
b. Question, maksudnya menyusun daftar pertanyaan yang terlevan dengan teks.

c. Read, maksudnya membaca teks secara aktif untuk mencari jawaban atas pertanyaanpertanyaan yang telah tersusun.

d. Recite, maksudnya menghafal setiap jawaban yang telah di temukan.

e. Review, maksudnya meninjau ulang seluruh jawaban atas pertanyaan yang tersusun pada langkah kedua dan ketiga.

\section{Manfaat Metode $\mathrm{SQ}_{3} \mathrm{R}$}

(Syah, 2013, hlm. 150)Metode SQ3R memberikan kesempatan kepada para pembaca untuk bersifat fleksibel. Pengaturan pencepatan membaca untuk setiap bagian bacaan tidaklah sama. Pembaca akan memperlambat tempo kecepatan membaca untuk hal-hal tertentu yang sangat di butuhkannya. Sebaiknya, dia akn menjadikan tempo bacaannya, jika bagian- bagian bacaan itu kurang relevan dengan kebutuhan atau hal-hal yang sudahdi kenalinya. Manfaat lain, pembaca di bekali dengan sesuatu metode belajar yang sistematis, dengan metode ini pencapaian hhasil belajar dengan efektif dan efesien akan terjamin apa bila di bandingkan dengan belajar tampa metode.

\section{Deskripsi Kondisi Awal}

Sebelum tindakan dilaksanakan, peneliti terlebih dahulu melaksanakan pre- test berupa teks bahasa Arab pada hari rabu tanggal 31 bulan mei tahun 2017. Ini dilakukan untuk mengetahui tingkat pengetahuan siswa sebelum diterapkannya metode $\mathrm{SQ}_{3} \mathrm{R}$ siswa terlihat kurang memahami teks yang peneliti berikan. KKM pada penelitian adalah sebesar 75 . Hal ini dapat dilihat dari hasil pre-test di bawah ini.

Tabel 1. Hasil Penilaian Pada Pre Test

\begin{tabular}{|c|l|c|c|c|l|c|}
\hline No & \multicolumn{1}{|c|}{ Nama } & Qaidah & & Mufrodat & $\begin{array}{l}\text { Kandungan } \\
\text { Makna }\end{array}$ & Nilai Akhir \\
\hline $\mathbf{1}$ & AELIAH & 20 & & 30 & 30 & 80 \\
\hline $\mathbf{2}$ & AMANAH & 30 & & 30 & 30 & 90 \\
\hline 3 & AMELIA & 10 & & 10 & 30 & 50 \\
\hline
\end{tabular}




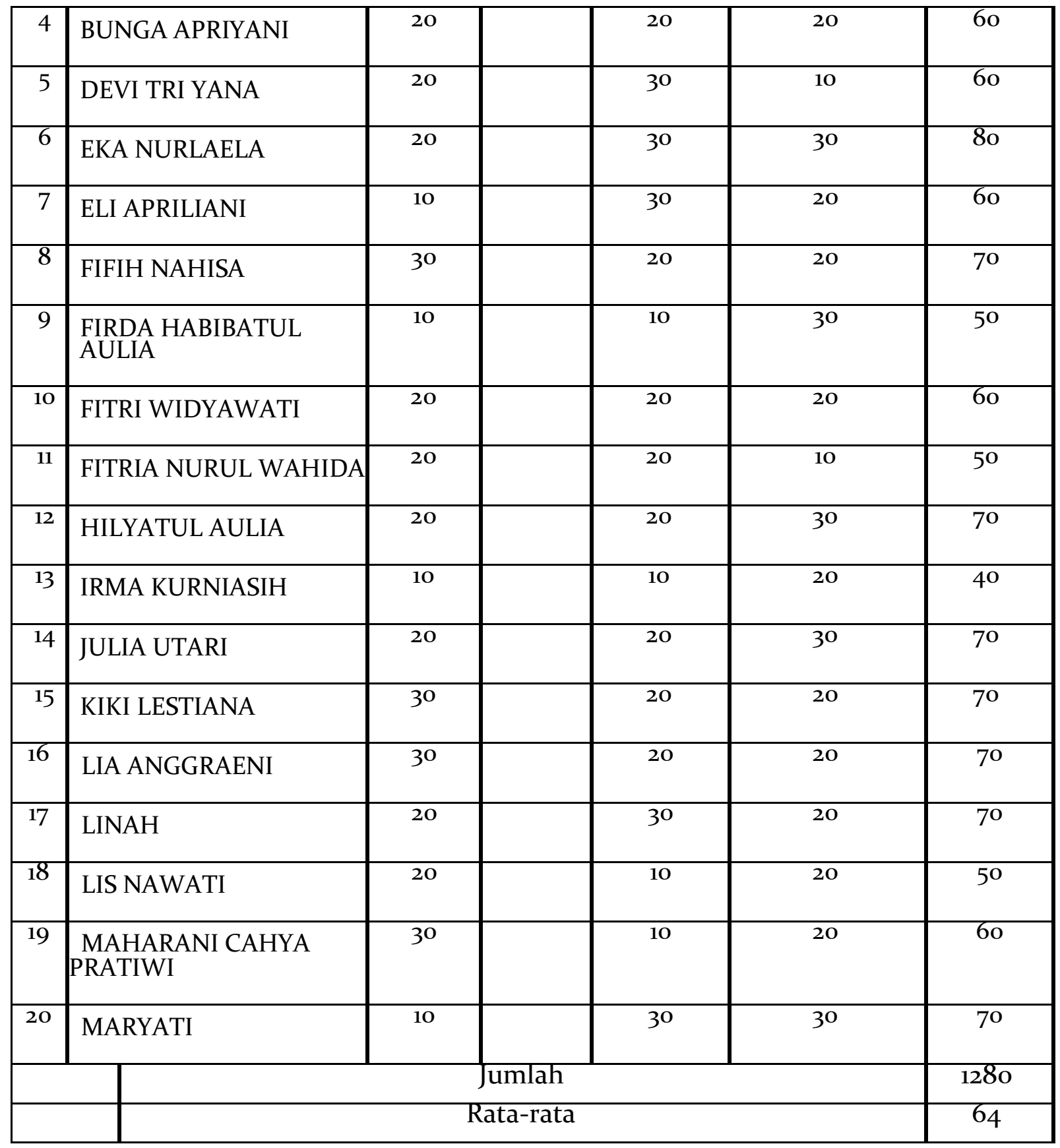

Dari hasil pre-test di atas menunjukan bahwa kemampuan pemahaman siswa terhadap teks bahasa Arab masih di bawah standar, hal ini dapat diketahui dari hasil nilai pre-test yang menunjukan hanya tiga siswa saja yang mencapai nilai KKM. Walaupun sudah terdapat beberapa siswa yang mendapatkan nilai yang bagus. Melalui pre-test ini hanya didapatkan rata-rata 64 dari seluruh siswa, oleh karena itu peneliti berusaha untuk memperbaiki sistem pembelajaran bahasa Arab yaitu dengan menerapkan metode $\mathrm{SQ}_{3} \mathrm{R}$ 
dalam meningkatkan pemahaman teks bahasa Arab siswa kelas VII B MTs Nurul Yaqin LegokTangerang.

Berdasarkan hasil Post-Test siklus 1 tersebut dapat disebutkan bahwa:

a. Terdapat 1 orang mendapatkan nilai 40 dari keseluruhan indikator

b. Terdapat 4 orang mendapatkan nilai 50 dari keseluruhan indikator

c. Terdapat 5 orang mendapatkan nilai 60 dari keseluruhan indikator

d. Terdapat 7 orang mendapatkan nilai 70 dari keseluruhan indikator

e. Terdapat 2 orang mendapatkan nilai 80 dari keseluruhan indikator

f. Terdapat 1 orang mendapatkan nilai 90 dari keseluruhan indikator

\section{Deskripsi Tindakan Siklus 1}

Siklus I peneliti laksanakan pada hari jum'at tanggal 2 bulan Juni tahun 2017 . Pembelajaran berlangsung selama 2X40 menit yang dilalui dengan langkah-langkah yang telah direncanakan Peneliti menggunakan metode yang sudah dipilih untuk diterapkan pada proses pelaksanaan pembelajaran yaitu metode $\mathrm{SQ}_{3} \mathrm{R}$, yaitu metode yang digunakan untuk meningkatkan kualitas pemahaman siswa terhadap kandungan makna yang ada pada sebuah teks bahasa Arab.

Berdasarkan hasil pengamatan dapat diketahui bahwa setelah diterapkannya metode SQ3R di kelas VII B, pemahaman siswa terhadap teks bahasa Arab tampak meningkat. Namun masih ada beberapa siswa yang masih pasif dan belum antusias dalam mengikuti pembelajaran. Hal ini juga dikarenakan metode yang digunakan peneliti masih terdapat kekurangan yang menyebabkan pemahaman teks bahasa Arab beberapa siswa masih kurang ataupun belum ada kemajuan. Semua ini juga dapat dilihat dari lembar observasi siswa ketika menjalani kegiatan proses belajar. Pada tahap selanjutnya peneliti ingin mengetahui peningkatan pemahaman siswa pada sebuah teks bahasa Arab dengan melakukan post test siklus 1 agar dapat dketahui peningkatannya setelah menerapkan metode SQ3 $\mathrm{R}$. Berikut ini hasil post test siklus 1

Tabel 2. Hasil Penilaian Post Test Siklus 1

\begin{tabular}{|c|c|c|c|l|c|}
\hline No & Nama & Qaidah & Mufrodat & Kandungan Makna & $\begin{array}{c}\text { Nilai } \\
\text { Akhir }\end{array}$ \\
\hline
\end{tabular}




\begin{tabular}{|c|c|c|c|c|c|}
\hline 1 & AELIAH & 30 & 30 & 30 & 90 \\
\hline 2 & AMANAH & 30 & 30 & 40 & 100 \\
\hline 3 & AMELIA & 20 & 20 & 30 & 70 \\
\hline 4 & BUNGA APRIYANI & 30 & 30 & 30 & 90 \\
\hline 5 & DEVI TRI YANA & 20 & 30 & 30 & 80 \\
\hline 6 & EKA NURLAELA & 20 & 30 & 40 & 90 \\
\hline 7 & ELI APRILIANI & 30 & 30 & 30 & 90 \\
\hline 8 & FIFIH NAHISA & 30 & 20 & 40 & 90 \\
\hline 9 & $\begin{array}{l}\text { FIRDA HABIBATUL } \\
\text { AULIA }\end{array}$ & 30 & 20 & 30 & 80 \\
\hline 10 & FITRI WIDYAWATI & 20 & 20 & 30 & 70 \\
\hline 11 & FITRIA NURUL WAHIDA & 30 & 20 & 30 & 80 \\
\hline 12 & HILYATUL AULIA & 20 & 20 & 40 & 80 \\
\hline 13 & IRMA KURNIASIH & 20 & 20 & 30 & 70 \\
\hline 14 & JULIA UTARI & 20 & 20 & 40 & 80 \\
\hline 15 & KIKI LESTIANA & 30 & 20 & 30 & 80 \\
\hline 16 & LIA ANGGRAENI & 30 & 30 & 40 & 100 \\
\hline 17 & LINAH & 20 & 30 & 30 & 80 \\
\hline 18 & LISNAWATI & 20 & 30 & 30 & 80 \\
\hline 19 & $\begin{array}{l}\text { MAHARANI CAHYA } \\
\text { PRATIWI }\end{array}$ & 30 & 20 & 40 & 90 \\
\hline 20 & MARYATI & 30 & 30 & 30 & 90 \\
\hline \multicolumn{5}{|c|}{ Jumlah } & 1680 \\
\hline \multicolumn{5}{|c|}{ Rata-rata } & 84 \\
\hline
\end{tabular}

Penulis menyimpulkan bahwa penerapan metode $\mathrm{SQ}_{3} \mathrm{R}$ mampu meningkatkan pemahaman siswa pada sebuah teks bahasa Arab. Pada hasil post-test menunjukan adanya 
peningkatan pemahaman teks yang dimiliki siswa kelas VII B dibandingkan dengan hasil pretest yang penelti berikan dengan tanpa menggunakan metode $\mathrm{SQ}_{3} \mathrm{R}$. Walalupun di

samping itu masih terdapat beberapa siswa yang masih canggung mengikuti pembelajaran dengan menggunakan metode $\mathrm{SQ}_{3} \mathrm{R}$. Sehingga menyebabkan siswa masih rendah dalam memahami teks bahasa Arab Sehingga dapat disimpulkan bahwa pada kegiatan siklus I ini terdapat peningkatan pemahaman siswa terhadap teks bahasa Arab dengan perbandingan rata-rata 20 dari nilai Pre-Test yang hanya mendapat rata-rata 64 dan rata-rata 84 yang didapatkan dari hasil Post-Test setelah pelaksanaan tindakan pada siklus I.

Berdasarkan hasil Post-Test siklus 1 tersebut dapat disebutkan bahwa:

a. Terdapat 3 orang mendapatkan nilai 70 dari keseluruhan indikator,

b. Terdapat 8 orang mendapatkan nilai 80 dari keseluruhan indikator,

c. Terdapat 7 orang mendapatkan nilai 90 dari keseluruhan indikator,

d. Dan terdapat 2 Orang Mendapatkan Nilai 100 Dari Keseluruhan indikator.

\section{Deskripsi Tindakan Siklus 2}

Pelaksanaan siklus II inipun dilaksanakan dengan 1x pertemuan dengan waktu yang sama seperti yang ada pada siklus I, yaitu 2X40 menit. Langkah- langkah yang akan peneliti laksanakan pun dilakukan sebagaimana skenario yang sudah disusun. Pada siklus II menggambarkan KBM yang lebih efisien dalam penggunaan waktu serta lebih baik dan terstruktur dalam setiap langkah pembahasan materi. Dengan ini pun peneliti menyimpulkan bahwa siklus II yang peneliti laksanakan dalam pembelajaran bahasa Arab dengan menggunakan metode $\mathrm{SQ}_{3} \mathrm{R}$ mampu meningkatkan pemahaman teks bahasa Arab.

Tabel 3. Hasil Penilaian Post Test Siklus 2

\begin{tabular}{|l|l|c|c|c|c|}
\hline No & \multicolumn{1}{|c|}{ Nama } & Qaidah & Mufrodat & $\begin{array}{c}\text { Kandungan } \\
\text { Makna }\end{array}$ & $\begin{array}{c}\text { Nilai } \\
\text { Akhir }\end{array}$ \\
\hline 1 & AELIAH & 30 & 30 & 40 & 100 \\
\hline
\end{tabular}




\begin{tabular}{|c|c|c|c|c|c|}
\hline 2 & AMANAH & 30 & 30 & 40 & 100 \\
\hline 3 & AMELIA & 30 & 30 & 30 & 90 \\
\hline 4 & BUNGA APRIYANI & 30 & 30 & 40 & 100 \\
\hline 5 & DEVI TRI YANA & 30 & 30 & 30 & 90 \\
\hline 6 & EKA NURLAELA & 30 & 30 & 40 & 100 \\
\hline 7 & ELI APRILIANI & 30 & 30 & 40 & 100 \\
\hline 8 & FIFIH NAHISA & 30 & 30 & 40 & 100 \\
\hline 9 & $\begin{array}{l}\text { FIRDA HABIBATUL } \\
\text { AULIA }\end{array}$ & 30 & 30 & 30 & 90 \\
\hline 10 & FITRI WIDYAWATI & 20 & 30 & 40 & 90 \\
\hline 11 & $\begin{array}{l}\text { FITRIA NURUL } \\
\text { WAHIDA }\end{array}$ & 30 & 30 & 30 & 90 \\
\hline 12 & HILYATUL AULIA & 30 & 30 & 40 & 100 \\
\hline 13 & IRMA KURNIASIH & 20 & 30 & 40 & 90 \\
\hline 14 & JULIA UTARI & 20 & 30 & 40 & 90 \\
\hline 15 & KIKI LESTIANA & 30 & 30 & 30 & 90 \\
\hline 16 & LIA ANGGRAENI & 30 & 30 & 40 & 100 \\
\hline 17 & LINAH & 30 & 30 & 40 & 100 \\
\hline 18 & LISNAWATI & 30 & 30 & 30 & 90 \\
\hline 19 & $\begin{array}{l}\text { MAHARANI CAHYA } \\
\text { PRATIWI }\end{array}$ & 30 & 30 & 40 & 100 \\
\hline 20 & MARYATI & 30 & 30 & 40 & 100 \\
\hline \multicolumn{5}{|c|}{ Jumlah } & 1.910 \\
\hline \multicolumn{5}{|c|}{ Rata-rata } & $95 \cdot 5$ \\
\hline
\end{tabular}

Dari hasil tes siklus II peneliti mendapatkan kejelasan nilai yaitu dengan jumlah nilai 1910 yang mencakup jumlah keseluruhan indikator peningkatan pemahaman teks siswa dengan 
perolehan rata-rata 95.5. Ini menunjukan tingkat pemahaman teks bahasa Arab siswa meningkat lebih tinggi dibandikan dengan hasil post tes pada siklus I yaitu dengan perolehan nilai hanya rata-rata 84 dari semua indikator yang ada.

Berdasarkan hasil Post-Test Siklus II tersebut dapat disebutkan bahwa:

a. Terdapat 9 orang mendapatkan nilai 90 dari keseluruhan indikator.

b. Terdapat 11 orang mendapatkan nilai 100 dari keseluruhan indikator.

\section{KESIMPULAN}

Dengan ini maka peneliti menyimpulkan bahwa adanya peningkatan pemahaman teks bahasa Arab siswa kelas VII B MTs Nurul Yaqin Legok- Tangerang dengan perolehan rata-rata 64 pada kegiatan pre-test, kemudian meningkat pada siklus I dengan rata-rata 84, lalu meningkat kembali pada siklus II dengan hasil rata-rata 95.5. Berikut peneliti lampirkan tabel diagram hasil penelitian yang telah dilaksanakan di kelas VII B MTs Nurul Yaqin dalam meningkatkan pemahaman teks bahasa Arab siswa.

\section{Tabel Diagram 3.}

Perbandingan Hasil Nilai Pre-Test, Post-Test Siklus 1, dan Post-Test Siklus II

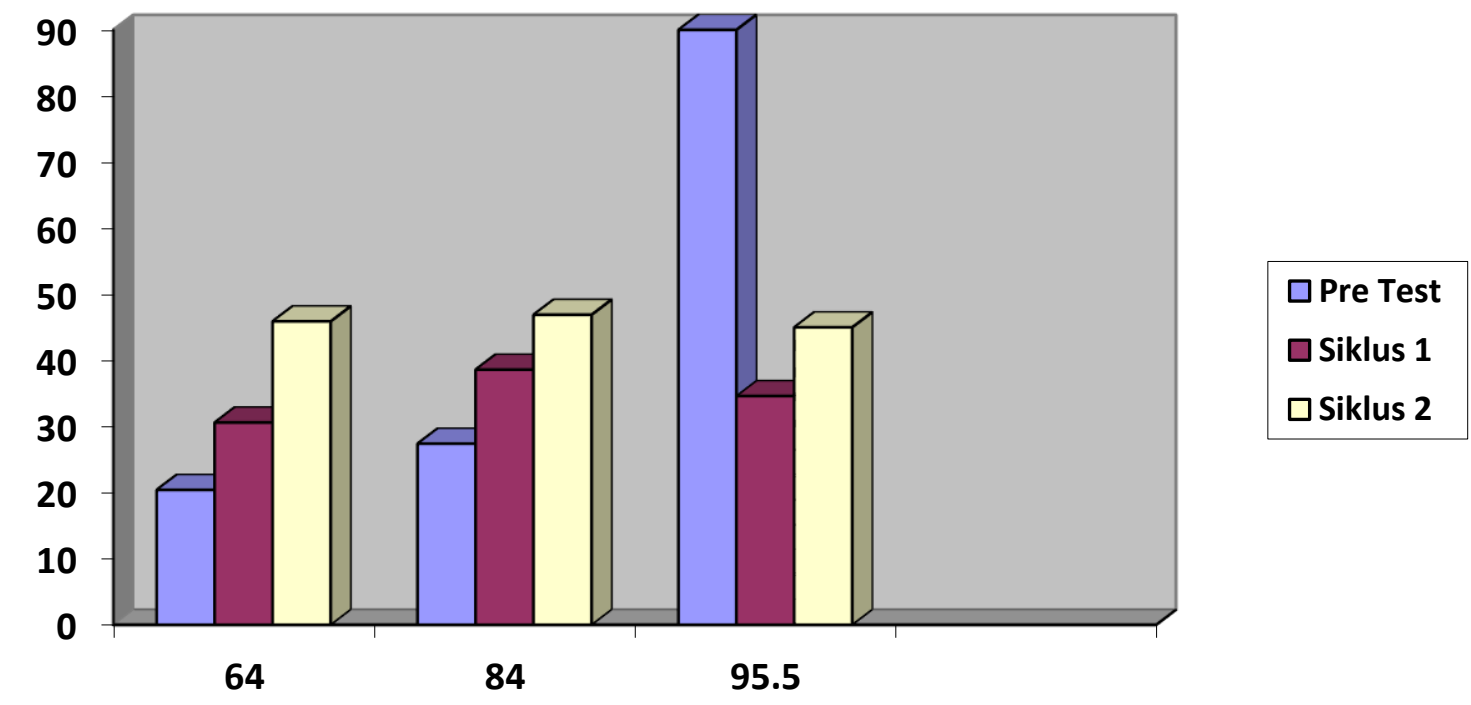

\section{DAFTAR PUSTAKA}

Ta'limi: Journal of Arabic Education \& Arabic Studies, Vol. 1 No. 1, Januari 2022: 21-33. 
Abidin, Y. (2012). Pembelajaran Membaca Berbasis Pendidikan Karakter. Refika Aditama.

Akbar, M. S. (2020). Pengaruh Metode $S_{3} R$ Pada Maharah Al-Qiraah Siswa Dalam Pembelajaran Bahasa Arab Kelas X-Mia Ma Muhammadiyah 1 Malang [Skripsi]. Universitas Muhammadiyah Malang.

Ambarwati, W. (t.t.). Peningkatan Keterampilan Membaca Pemahaman Melalui Metode SQ3R di SDN o1 Pajerukan. Jurnal Tarling, 2(1).

Aminah, S. A. \& Emilda. (2020). Penggunaan SQ3R Dalam Meningkatkan Kemampuan Membaca Siswa. , Jurnal Bahasa, Sastra, dan Pengajaran, 9(1), 55-63.

Ardila, R., \& Hidayah, L. W. (2018). Penerapan Metode Sq3r Untuk Meningkatkan Kemampuan Membaca Intensif Siswa Kelas Ix Mts Nahdliyatul Islamiyah Blumbungan Pamekasan. Jurnal Pemikiran, Penelitian Pendidikan dan Sain, 6(2), 192-206.

Bahri, S. D. (2008). Rahasia Sukses Belajar (Revisi). Rineka Cipta.

Burham, J. (2017). Upaya Peningkatan Ketrampilan Membaca Pemahaman Teks Deksriptif Bahasa Inggris Melal (parhan)ui Penerapan Metode SQ3R. Entrance Jurnal Pendidikan, 1(1), 1-14.

Dalman. (2013). Keterampilan Membaca. Rajawali Pers.

Huda, M. (2014). Mode-Model Pengajaran dan Pembelajaran. Pustaka Belajar.

Huda, M. (2015). Cooperative Learning (Cet. IX). Pustaka Pelajar.

Limguistik, P. N., \& Kalam, M. A. ئرلا تاملكلا تَيسي.

Russamsi, Y. (2017). Upaya meningkatkan hasil belajar siswa pada pembelajaran bahasa arab materi membaca dengan menggunakan metode $S_{3}$ [Skripsi]. UIN Sunan Gunung Djati Bandung.

Sastradiharja, E. J. (2018). Pengaruh Supervisi Akademik Kepala Sekolah Dan Kompetensi Paedagogik Terhadap Kinerja Guru. alashriyyah, 4(2), 10-10.

Syah, M. (2013). Psikologi Belajar. Raja Grafindo Persada.

Ubaidillah. (2017, Februari 15). Wawancara guru pamong kelas VsII Mts Nurul Yaqinlegok Tangerang [Komunikasi pribadi]. 